\title{
Bisnis Online Agent Ilegal dalam Perkembangan Industri Pariwisata Bali
}

\author{
I Gusti Ayu Putu Widia Wijayanti \\ Operation Staff PT. Pacto Bali Tour and Travel
}

widiawijayanti90@yahoo.com

\begin{abstract}
The increasing number of illegal online travel agencies recently has become a hot issue that being discussed by the entrepreneurs of tourism business service in Bali. This kind of business has triggered tariff competition, which is unhealthy and has negative impact on the existence of travel agency business in Bali. Therefore, this phenomenon becomes an interesting issue to be investigated. Aims of the investigation were to know the growth of illegal online travel agent business, its impacts and to formulate policies for controlling it that are more relevant to present condition, creating conducive, harmonious, and balanced tourism business in Bali. The impacts of illegal online travel agents were classified into economic, social, culture, and impacts on images. Dealing with illegal online travel agent business, it was observed that there was no negative impacts of tourist. The tourist stated that they were remain satisfied to the services given by illegal online travel agents. The effort made by the governments was still limited on providing suggestion, because there has not been a strong punishment for the offender. Thus, it is recommended that there is a need to set up a policy to control illegal online travel agent in Bali. The local government should formulate more effective and efficient policies, to restore the harmony and balanced conditions of tourism business in Bali. In addition, for the travel agency management, they should obey the law and regulations in running the business.
\end{abstract}

Keywords: Illegal Online Travel Agent, Tourism Industry.

\section{Pendahuluan}

Pariwisata merupakan salah satu sektor yang sangat diandalkan dalam pembangunan nasional karena pariwisata dapat meningkatkan pendapatan nasional dan pendapatan daerah serta devisa negara. Terlebih bagi negara berkembang seperti Indonesia yang memiliki potensi wilayah yang luas dengan daya tarik wisata yang cukup besar, banyaknya keindahan alam, aneka warisan sejarah budaya, dan kehidupan masyarakatnya. Pariwisata di Indonesia merupakan salah satu penunjang perekonomian yang memiliki prospek cerah yang dapat berperan dalam menciptakan kesejahteraan masyarakat.

Salah satu pulau di Indonesia yang banyak menarik minat wisatawan untuk dikunjungi adalah Pulau Bali yang memiliki beraneka ragam kebudayaan dan adat istiadatnya, sehingga Pulau Bali mampu menjadi icon pariwisata di Indonesia.Berdasarkan data yang dikeluarkan oleh Badan Pusat Statistik Provinsi Bali Tahun 2016, kunjungan wisatawan domestik dan mancanegara ke Pulau Dewata mengalami pertumbuhan yang cukup baik. Adapun jumlah kunjungan wisatawan mancanegara pada tahun 2016 mencapai 4.927 .937 yang mengalami peningkatan $23.14 \%$ dari tahun 2015 yaitu 4.001.836. Tingginya jumlah kunjungan wisatawan dan perkembangan sektor pariwisata maka akan terjadi permintaan yang tinggi dari para wisatawan untuk memenuhi kebutuhan mereka.

Perkembangan teknologi yang semakin canggih dan juga keinginan serta kebutuhan masyarakat yang ingin serba praktis menyebabkan perkembangan berwisata dewasa ini dipengaruhi dunia online.Jumlah transaksi secara online yang terus meningkat dari tahun ke tahun menunjukkan bahwa bisnis online akan semakin berkembang, dan diperkirakan trend ini akan terus berlanjut selama lima tahun ke depan.

Munculnya bisnis ilegal yang ditekankan dalam tulisan ini adalah Biro Perjalanan Wisata atau agent-agent yang dapat beroperasi secara online dan tidak memiliki izin. Jasa penyedia layanan wisata online yang ilegal di Bali berkembang dengan sangat cepat, ada yang berbentuk perusahaan, bahkan lebih banyak dilakukan oleh perseorangan. Beranjak dari kenyataankenyataan tersebut, akan disikapi sebagai suatu masalah yang harus segera dicermati dan ditindaklanjuti. Jika tidak, tentu hal itu akan berdampak pada rendahnya kualitas pelayanan industri pariwisata di masa mendatang.

Sebelum membahas lebih mendalam tentang bisnis travel agent ilegal dalam perkembangan industri pariwisata Bali, maka terlebih dahulu perlu disampaikan beberapa konsep atau pengertian dari Industri Pariwisata, Travel Agent dan Online Travel Agent Ilegal, seperti yang diuraikan di bawah ini. 
Industri pariwisata adalah kumpulan usaha pariwisata yang saling terkait dalam rangka menghasilkan barang dan/atau jasabagi pemenuhan kebutuhan wisatawan dalam penyelenggaraan pariwisata (Undang-Undang RI No.10 Tahun 2009 Tentang Kepariwisataan). Industri Pariwisata, dapat diartikan sebagai: sehimpunan bidang usaha yang menghasilkan berbagai jasa dan barang yang dibutuhkan oleh mereka yang melakukan atau berada dalam perjalanan. Secara nyata, seseorang yang berada dalam perjalanan membutuhkan barang dan jasa dari berbagai bidang usaha, bukan hanya satu, sekurang-kurangnya ia membutuhkan jasa angkutan, jasa akomodasi, jasa hidangan ditambah dengan jasa-jasa lain yang erat hubungannya dengan kebutuhan kunjungan/perjalanannya. Bila barang dan jasa tersebut dihimpun/dipersatukan dalam bentuk satu program perjalanan, dengan dibatasi oleh dimensi ruang (jarak, tempat) dan dimensi waktu, maka akan terbentuk suatu produk daripada Industri Pariwisata. Kesatuan produk pariwisata ini lazimnya ditawarkan dalam bentuk paket (package), meskipun tidak menutup kemungkinan untuk wistawan menghimpun sendiri masing-masing komponen/unsur tersebut, dengan cara merangkainya sendiri. Pada dasarnya yang dimaksud dengan produk industri pariwisata adalah semua jasa-jasa (service) yang dibutuhkan wisatawan semenjak ia berangkat meninggalkan rumah sampai di daerah tujuan wisata yang telah dipilihnya, sampai ia kembali ke rumah tempat tinggalnya.

Jadi kesimpulannya bahwa industri pariwisata adalah kumpulan usaha pariwisata yang saling terkait dalam rangka memberikan pelayanan kepada wisatawan semenjak ia berangkat dari daerah asalnya sampai di daerah tujuan wisata, serta sampai ia kembali lagi ke daerah asalnya. Adapun kumpulan usaha yang dimaksud, meliputi : usaha transportasi, usaha akomodasi, usaha restoran, usaha daya tarik dan atraksi wisata, serta usaha Biro Perjalanan Wisata (Travel Agent).

Menurut Bagyono (2005:60) pengertian dari travel agent dapat diuraikan sebagai berikut :

1. Bersifat komersial, yakni usaha yang dijalankan sepenuhnya untuk mendapatkan keuntungan.

2. Mengatur, menyediakan dan menyelenggarakan pelayanan. Kegiatan travel agent adalah usaha yang menjual jasa. Oleh karena itu perusahaan tersebut akan mendapatkan imbalan tertentu dari jasa yang dijualnya.

3. Ditujukan bagi seseorang atau sekelompok orang, artinya bahwa perjalanan melaksanakan kegiatan untuk dinikmati oleh perorangan (individu) atau sekelompok orang (group).

4. Ditujukan untuk kegiatan perjalanan dengan tujuan utama berwisata. Maksudnya bahwa usaha perjalanan melayani kegiatan perjalanan apapun, misalnya bisnis, olahraga, kesehatan, dan lain-lain.

Menurut Yoeti (2002:58), travel agent adalah suatu perusahaan yang memperoleh pendapatan dan keuntungan dengan menawarkan dan menjual produk serta jasa-jasa pelayanan yang diberikan kepada pelanggannya.

Menurut Foster (2000:77), travel agent adalah sebuah perusahaan yang menjual rancangan perjalanan secara langsung pada masyarakat dan lebih khusus lagi menjual transportasi udara, darat, laut, akomodasi penginapan, pelayanan wisata, wisata paket, asuransi perjalanan dan produk lainnya yang berhubungan.

Jadi dapat disimpulkan travel agent dapat diartikan sebagai suatu usaha perjalanan yang menjual jasa perjalanan wisata, informasi wisata, tiket penerbangan, jasa akomodasi (hotel), dan segala hal yang dibutuhkan wisatawan secara umum saat berwisata.

Travel agent merupakan elemen penting dalam proses pelayanan terhadap wisatawan. Saat ini hampir sebagian besar wisatawan menggunakan jasa travel agent. Peranan travel agent dalam hal ini hampir sama dengan biro perjalanan wisata yaitu sebagai salah satu jembatan bagi wisatawan untul dapat menikmati objek wisata pada suatu Daerah Tujuan Wisata (DTW).

Berdasarkan batasan termaktub dalam Penjelasan atas Undang Undang Nomor 10 Tahun 2009 tentang Kepariwisataan pada Bab VI Pasal 14 (d), yang dimaksud dengan usaha biro perjalanan wisata meliputi usaha penyediaan jasa perencanaan perjalanan dan/atau jasa pelayanan dan penyelenggaraan pariwisata, termasuk penyelenggaraan perjalanan ibadah, sedangkan agen perjalanan wisata meliputi usaha jasa pemesanan sarana, seperti pemesanan tiket dan pemesanan akomodasi serta pengurusan dokumen perjalanan.

Biro perjalanan wisata secara historis telah berperan sebagai agen besar (wholesaler) sejak pertengahan abad ke-19 atau pada tahun 1841, ketika Thomas Cook men-charter kereta api membawa ratusan orang menghadiri pertemuan yang membicarakan laranga minuman keras, yang jaraknya 200 mil. Thomas Cook memimpin wisata akbar ke Eropa (Mill, 2000). Ada perbedaan definisi antara operator wisata dengan agen wisata besar atau biro perjalanan wisata (Mill, 2000). Operator wisata (tour operator) adalah menjual paket wisata langsung kepada masyarakat, sedangkan agen wisata besar (wholesale travel agency) adalah menjual paket wisata tidak 
langsung kepada masyarakat melainkan melalui agen-agen kecil lainnya. Dari pengertian tersebut agen wisata lebih cenderung mengkhususkan segmen pada pangsa pasar wisatawan tertentu.

Fungsi dan peranan travel agent adalah sebagai berikut :

1. Sebagai Perantara (Intermediary)

Perusahaan perjalanan berperan sebagai perantara antara calon wisatawan dengan perusahaan-perusahaan industri pariwisata lain seperti perusahaan transportasi, akomodasi, hiburan, dan lain-lain. Apabila dipandang dari kacamata wisatawan maka travel agent merupakan tempat wisatawan memperoleh informasi tentang segala sesuatu di daerah tujuan wisata, tempat wisatawan meminta bantuan untuk mengurus dokumen-dokumen perjalanan, tempat wisatawan memesan dan membeli tiket penerbangan dan voucher hotel, tempat wisatawan meminta bantuan mengenai segala sesuatu yang berhubungan dengan perjalanan.

2. Sebagai Organizer

Sebagai organizer, suatu perusahaan perjalanan harus mampu mempertemukan wisatawan selaku konsumen dan pengusaha industri pariwisata sebagai supplier, mempersiapkan macam-macam tour yang mungkin dapat ditawarkan kepada calon wisatawan, memiliki keahlian dalam mengatur, dan menggali atraksi wisata yang mungkin dapat menarik kedatangan wisatawan.

Penjelasan tersebut menunjukkan bahwa degan jelas tampak travel agent adalah sebagai jembatan penghubung antara penyedia kebutuhan wisata dengan para calon pelanggan yang akan menggunakan atau menikmati apa yang dibutuhkan. Peran travel agent tidak hanya terbatas pada hal tersebut tetapi memberikan pelayanan, petunjuk, bantuan dalam merencanakan perjalanan serta menyediakan kebutuhan-kebutuhan lain yang diperlukan bagi wisatawan untuk melakukan perjalanan wisata.

Perkembangan pariwisata membuat makin berkembangnyaa industri perjalanan wisata seperti travel agent atau media transportasi lainnya. Travel agent sangat membantu dalam melakukan suatu kegiatan kepariwisataan karena menjadi jembatan penghubung dan penyalur keinginan wisatawan dalam melakukan kegiatan kepariwisataan. Travel agent mempunyai fungsi mengkoordinasikan, mengorganisasi serta menyelenggarakan perjalanan wisata. Menurut Surat Keputusan Direktur Jendral Pariwisata No. Kep 16/U/II/88 tanggal 25 Februari 1988 tentang pelaksanaan ketentuan usaha perjalanan pada Bab 1 Penelitian Umum Pasal 1, memberikan pengertian travel agent dengan batasan sebagai berikut, travel agent adalah badan usaha yang menyelenggarakan usaha perjalanan yang bertindak sebagai perantara didalam menjual dan atau mengurus jasa untuk melakukan perjalan. Jadi travel agent adalah suatu badan usaha yang bertindak sebagai pihak yang membantu merencanakan, menyiapkan dan mengadakan suatu perjalanan.

Travel agent membantu wisatawan dalam memilih perjalanan hingga hotel yang diinginkan. Wisatawan dimana sebagai konsumen dapat memilih paket, jenis transportasi ataupun akomodasi yang ditawarkan. Travel agent tidak hanya menjual paket wisata yang ditawarkan oleh Biro Perjalanan Wisata (BPW), tetapi mulai menawarkan transportasi dan akomodasi karena ada kesinambungan antara kegiatan pariwisata dengan akomodasi dan transportasi. Travel agent memiliki fungsi mengkoordinasi, mengorganisasi serta menyelenggarakan perjalanan wisata yang memilki tujuan menyiapkan suatu perjalanan bagi seseorang yang merencanakan untuk pengadaan perjalanan (Pendit 1976:56).

Online travel agent adalah suatu badan usaha yang memfasilitasi konsumen dengan penyediaan pengadaan suatu perjalanan namun di fasilitas penawaran produk yang dilakukan melalui jalur online, mulai dari pemilihan produk, pemesanan tanggal kegiatan hingga transaksi pembayaran yang semua dilakukan melalui jalur koneksi internet. Sistem pemasaran dan penjualan dilakukan melalui webiste-website tertentu.

Internet sebagai rangkaian atau jaringan sejumlah komputer yang saling berhubungan. Internet berasal dari kata interconnected-networking. Internet merupakan jaringan global yang menghubungkan suatu jaringan (network) dengan jaringan lainnya di seluruh dunia. Media yang menghubungkan bisa berupa kabel, kanal satelit, ataupun frekuensi radio. Jaringan internet bekerja berdasarkan suatu protocol (aturan). Transmission Control Protocol/Internet Protocol (TCP/IP) adalah protocol standar yang digunakan unuk menghubungkan jaringan-jaringan di dalam internet sehingga data dapat dikirim dari satu computer ke komputer lainnya. Setiap komputer diberikan suatu nomor unik yang disebut dengan alamat Identity Personel (Wira, 2009).

Website merupakan salah satu media pemasaran bagi perusahaan atau perorangan yang difungsikan sebagai media komunikasi untuk menyediakan informasi bagi pasar sasarannya dan sebagai media trasaksi untuk memfasilitasi aktivitas transaksi secara online. Sebagai media pemasaran, website diharapkan memiliki kinerja yang baik. Kinerja suatu website dilihat dari output yang dihasilkan oleh website tersebut (Eagleton and Dobler, 2007: 164). 
Semakin berkembangnya zaman membuat semakin pesatnya perkembangan teknologi informasi dan komunikasi salah satunya adalah internet yang menjadikan mudahnya koneksi antara satu dengan lainnya tanpa harus bertatap muka langsung. Melakukan pengiriman pesan tanpa pos, penyediaan informasi yang dibutuhkan, berbagai informasi maupun social media yang semakin mudah membuat industri travel agent online pun semakin mudah dalam menawarkan produk yang ada.

Online Travel Agent merupakan salah satu jenis travel agent yang seluruh kegiaatan transaksinya dilakukan secara online. Namun dengan adanya perkembangan Teknologi dan Informasi, menimbulkan banyaknya bisnis online travel agent yang berkembang, dan sebagian besar dari mereka beroperasi tanpa izin resmi. Banyaknya online travel agent yang tidak memiliki izin atau ilegal yang beroperasi di Bali mendapatkan keluhan dari online travel agent resmi yang telah memiliki izin Usaha Jasa Pariwisata.

Dalam Peraturan Daerah Provinsi Bali No. 1 Tahun 2010 dinas yang bertugas sebagai pengawas dalam pelaksanaan Biro Perjalanan Wisata di Provinsi Bali baik secara konvensional maupun online adalah Dinas Pariwisata Provinsi Bali. Hal ini sesuai dengan Pasal 13 dan 14 Undang-undang No. 32 Tahun 2004 tentang Pemerintahan Daerah dimana adanya pembagian kewenangan antara Pemerintah Pusat dengan Pemerintah Daerah. Dalam mengatasi bisnis online travel agent ilegal dapat dikenakan sanksi administratif sesuai dengan ketentuan Pasal 16 ayat (1) Peraturan Daerah Provinsi Bali No. 10 Tahun 2010 dimana "Setiap penyelenggaraan UJPW yang beroperasi tanpa Tanda Daftar Usaha sebagaimana dimaksud dalam Pasal 8 ayat (1), dikenakan sanksi administratif berupa penutupan tempat usaha." Tidak adanya pengaturan yang tegas dan jelas mengenai bisnis online travel agent ilegal menyebabkan semakin bertambah banyaknya online travel agent yang tidak memiliki izin beredar di dunia maya (Arsani Dkk, 2012).

Transaksi elektronik merupakan salah satu bentuk perbuatan hukum yang dilakukan dua atau lebih pihak, sehingga transaksi elektronik memerlukan kesepakatan dalam bentuk perjanjian, hal ini diatur dalam Pasal 1320 KUHPerdata. Sehingga secara hukum, penipuan secara online dapat diperlakukan sama sebagaimana delik konvensional yang diatur dalam Kitab UndangUndang Hukum Pidana (KUHP). Terhadap penipuan online travel agent ilegal dilakukan tindakan hukum pidana sesuai dengan Pasal 28 ayat (1) Undang-Undang Informasi dan Transaksi Elektronik (ITE) serta KUHP Pasal 378 tentang Penipuan (Arsani,2012).

\section{Pembahasan}

Jumlah keberadaan online travel agent ilegal sampai saat ini belum dapat terdeteksi oleh aparat penertiban dan pengendalian usaha pariwisata di Dinas Pariwisata Provinsi Bali mengingat usaha-usaha pariwisata tersebut tidak dapat terlihat dengan kasat mata karena beroperasi di dunia maya dan tersebar di seluruh pelosok baik desa maupun kota di wilayah bali. Maraknya bisnis online travel agent ilegal di Bali seiring dengan perkembangan teknologi informasi saat ini sangat menghawatirkan banyak pihak terutama dikalangan para pelaku pariwisata yang legal/resmi dan pemerintah maupun bagi usaha pariwisata secara luas. Hal ini akan menimbulkan dampak negatif yang lambat laun merusak citra (image) kepariwisataan di Bali.

Bagi wisatawan, keberadaan online travel agent ilegal ini ternyata tidak menimbulkan keresahan bahkan wisatawan merasa lebih nyaman memilih online tavel agent ilegal, karena harga yang ditawarkan lebih murah dan perjalanan wisata yang dilakukan sesuai dengan permintaan wisatawan, tidak seperti halnya pada agen-agen resmi yang menawarkan harga yang lebih mahal dan paket-paket wisata yang bersifat mengikat kebebasan wisatawan.

Timbulnya bisnis online travel agent ilegal tersebut lambat laun akan menimbulkan dampak yang meresahkan kalangan pelaku usaha biro perjalanan wisata resmi, tetapi disisi lain justru tidak menimbulkan dampak negatif terhadap wisatawan. Menurut hasil penelitian dilapangan, dengan adanya perkembangan teknologi informasi sangat mempengaruhi seseorang untuk dapak membuka peluang bisnis yang sangat menguntungakan bagi mereka, namun kerugian yang sangat besar bagi citra Pariwisata Bali di masa yang akan datang.

Banyaknya bisnis online travel agent ilegal di satu sisi memberi ruang yang menguntungkan bagi pihak-pihak yang mencari keuntungan dengan mengabaikan kewajibannya sebagai pengusaha, dan disisi lain menimbulkan keresahan bagi pengusaha resmi yang menjalankan usaha sesuai dengan norma dan ketentuan yang berlaku. Kondisi ini menimbulkan beberapa dampak, yaitu :

1. Dampak Ekonomi

Dampak di bidang ekonomi sangat menguntungkan bagi pelaku usaha ilegal, karena memberikan keuntungan dengan memperoleh rejeki dari penjualan usaha perjalanan yang diselenggarakan. Bagi pengusaha biro perjalanan resmi, hal ini merupakan 
ancaman bagi eksistensi usaha mereka karena mengakibatkan perang tarif, persaingan yang tidak sehat, serta dianggap menggangu ketertiban usaha pariwisata.

2. Dampak Sosial

Perkembangan teknologi informasi saat ini juga menimbulkan dampak di bidang sosial, yakni adanya perubahan pola konsumsi masyarakat yang awalnya melakukan kunjungan langsung ke kantor biro perjalanan wisata atau travel agent untuk mendapatkan informasi perjalanan, beralih pada internet yang bisa secara praktis, cepat, dan tanpa mengeluarkan biaya lebih memberikan informasi kepada calon wisatawan. Dampak yang negatif bagi dunia usaha perjalanan wisata dengan ditemukan banyaknya bisnis online travel agent yang tidak memiliki izin usaha,disisi lain dampak sosial yang ditimbulkan oleh keberadaan online travel agent ilegal adalah adanya pertentangan kepentingan muncul antara pelaku pariwisata resmi dengan pelaku pariwisata ilegal. Kondisi ini lambat laun akan menimbulkan konflik antar pelaku pariwisata.

3. Dampak Budaya

Dampak buruk yang muncul dengan adanya perkembangan teknologi informasi pada dunia pariwisata khususnya untuk bisnis online travel agent ilegal adalah mengakibatkan turunnya kesadaran masyarakat untuk membayar pajak, dan degradasi moral yang dulunya bersifat kebersamaan dengan solidaritas yang tinggi serta saling menghargai. Selain itu timbulnya sikap apatis antar pelaku pariwisata yang tentunya disebabkan oleh disharmoni dan ketidakseimbangan dalam dunia pariwisata tersebut.

Beberapa upaya yang bisa dijadikan rekomendasi yang dapat disarankan bagi pelaku bisnis online travel agent ilegal, antara lain :

1. Bagi perusahaan yang telah memiliki modal usaha yang memadai, diharapkan secara sadar segera mengurus kelengkapan perizinan usaha biro perjalanan wisata / agen perjalanan wisata.

2. Jika pengusaha yang memiliki modal usaha yang masih terbatas dan masih berusaha secara kecil-kecilan atau yang bersifat coba-coba, disarankan untuk sementara waktu bersedia bernaung di bawah biro perjalanan wisata resmi, yang selanjutnya dalam menjalankan kegiatan usaha atas nama biro perjalanan resmi tersebut.

3. Pengusaha sebaiknya bersedia meluangkan waktu untuk tidak malas untuk mengurus izin usaha.

4. Memberikan harga murah bagi wisatawan di bawah harga standar yang telah ditetapkan ASITA, akan menimbulkan persaingan harga yang tidak sehat bagi biro perjalanan wisata resmi. Hal ini tentu menyebabkan iklim usaha jasa pariwisata menjadi kurang sehat dan kondusif.

5. Mengurus izin usaha berarti secara tidak langsung memberikan pemasukan kas daerah, guna meningkatkan Pendapatan Asli Daerah (PAD) yang pada akhirnya digunakan untuk meningkatkan kualitas pembangunan dan kesejahteraan masyarakat.

\section{Penutup}

Berdasarkan hasil analisis dan pembahasan yang telah diuraikan sebelumnya, dapat simpulkan, sebagai berikut :

1. Pertumbuhan bisnis online travel agent ilegal di Bali seiring dengan perkembangan teknologi informasi saat ini sangat menghawatirkan banyak pihak terutama di kalangan para pelaku pariwisata yang legal/resmi dan pemerintah maupun bagi usaha pariwisata secara luas. Beberapa hal lain yang mendasari maraknya usaha ilegal ini adalah pengusaha yang malas mengurus izin, birokrasi yang rumit, terbatasnya modal usaha.

2. Dampak perkembangan teknologi informasi terhadap bisnis online travel agent ilegal di Bali, meliputi dampak ekonomi, dampak sosial, dampak budaya, serta dampak terhadap citra pariwisata Bali.

3. Upaya pengendalian bisnis online travel agent ilegal di Bali dapat dilakukan dengan penetapan sanksi berupa penutupan usaha dan ketentuan pidana kurungan beserta denda bagi pelanggar.

Adapaun beberapa saran yang penulis sampaikan adalah sebagai berikut :

1. Bagi para praktisi online travel agent ilegal dihimbau agar segera mengurus izin usaha, guna memperoleh legalitas perusahaan. 
2. Bagi pemerintah daerah, agar mensosialisasikan kriteria dan kelengkapan persyaratan sebuah travel agent atau biro perjalanan wisata serta mempermudahkan pengurusan birokrasi dan perizinan.

3. Bagi pihak akademisi agar dapat melaksanakan penelitian yang lebih mendalam menyangkut perkembangan bisnis online travel agent illegal di Bali, sehingga dapat dijadikan sebagai acuan pemerintah dalam mengambil kebijakan untuk penanggulangannya.

4. Bagi masyarakat dihimbau agar ikut berpartisipasi menjaga dan memperhatikan perkembangan lingkungannya guna mengantisipasi dan menertibkan usaha-usaha ilegal yang tidak mentaati tata tertib dan aturan pemerintah.

\section{Daftar Pustaka}

Anthony, R.N., Dearden, J., Bedford, N.M. 1992. Sistem Pengendalian Manajemen. Jilid I Edisi Keenam. (Agus Maulana). Jakarta: Binarupa Aksara.

Arsani, dkk. 2012. Pengawasan Terhadap Biro Perjalanan Wisata Online Yang Tidak Memiliki Izin di Provinsi Bali, Bagian Hukum Administrasi Negara Fakultas Hukum. Denpasar: Universitas Udayana.

Asmadi. 2003. Pendekatan Kualitatif dan Kuantitatif serta Kombinasinya Dalam Penelitian Psikologis. Yogyakarta: Pustaka Belajar.

Bhasma, I.B.A. 2003. Pengendalian Penduduk Pendatang di Desa Adat Ubung, Kota Denpasar (tesis). Denpasar: Universitas Udayana.

E.M. Rogers. 1983. Diffusion of Inovatio. New York: Free Press.

Foster, Dennis L. 2000. First Class An Introduction to Travel and Tourism, Second Edition. Jakarta: Raja Grafindo Persada.

Kartini Kartono. 1980. Pengantar Metodologi Research Sosial. Bandung: Alumni.

Koentjaraningrat. 1977. Metode Metode Penelitian Masyarakat. Jakarta: PT. Gramedia.

Koenig, S. 1957. Mand and Society, the basic teaching of Sociology. New York: Barners \& Noble Inc

Miles, B.M., Huberman, A.M. 1992. Analisis Data Kualitatif. Jakarta: Universitas Indonesia Press.

Nawawi, H.H. 1992. Instrumen Penelitian Bidang Sosial. Yogyakarta: Gajah Mada University Press.

Pendit, Nyoman S. 1976. Pariwisata: Sebuah Studi, Analisa dan Informasi. Jakarta: PT. Gramedia.

Ph.D, Arief Suhadi. 1996. Sistem Pengendalian Manajemen Edisi Ke-4. Yogyakarta: BPFE

Pitana, I.G., Gayatri P.G. 2005. Sosiologi Pariwisata. Yogyakarta: Andi Offset.

Poloma, M.M. 2007. Sosiologi Kontemporer. Jakarta: PT. Raja Grafindo Persada.

Ritzer, G. 2000. Sociological Theory. International Edition. Singapore: McGraw-Hill Book Co.

Soekanto, S. 1983. Beberapa Teori Sosiologi Tentang Struktur Masyarakat. Jakarta: Rajawali.

Soemardjan, S. 1962. Social Changes in Yogyakarta. New York: Cornell University Press.

Soemarlan, S. 2011. Pengaruh Pelayanan, Harga Dan Biaya Promosi Terhadap Online Booking Industri Villa Di Seminyak. Denpasar: Universitas Udayana.

Sudiarta, M. 2005. Faktor-Faktor Yang Mempengaruhi Kepuasan Wisatawan Terhadap Pelayanan Biro Perjalanan Wisata di Bali (tesis). Denpasar: Universitas Udayana.

Sumadi. 2009. Metodelogi Penelitian. Jakarta: Raja Grafindo.

Undang-Undang RI Nomor 10 Tahun 2009 Tentang Kepariwisataan. 
Wuisman, R. 1996. Penelitian Ilmu-Ilmu Sosial. Asas-asas (Jilid I). Jakarta: Lembaga Penerbit Fakultas Ekonomi Universitas Indonesia.

Yoeti A.H.O. 1995. Tour and Travel Manajement. Jakarta: PT. Pradnya Paramita.

Yoeti A.H.O. 2002. Perencanaan Strategis Pemasaran Daerah Tujuan Wisata. Jakarta: PT. Pradnya Paramita. 